\title{
PRODUCTION OF HYDROLYTIC ENZYMES BY TRICHODERMA ISOLATES WITH ANTAGONISTIC ACTIVITY AGAINST CRINIPELLIS PERNICIOSA, THE CAUSAL AGENT OF WITCHES' BROOM OF COCOA
}

\author{
Janice Lisboa De Marcoㅜㄹ Maria Cléria Valadares-Inglis ${ }^{2}$; Carlos Roberto Felix ${ }^{1 *}$ \\ ${ }^{1}$ Departamento de Biologia Celular. Universidade de Brasília, Brasília, DF, Brasil. ${ }^{2}$ Centro Nacional de Pesquisas de Recursos \\ Genéticos e Biotecnologia, Empresa Brasileira de Pesquisa Agropecuária, Brasília, DF, Brasil.
}

Submitted: July 29, 2002; Approved: December 05, 2002.

\begin{abstract}
Two isolates of Trichoderma, which reduce the incidence of witches'broom disease caused in cocoa by Crinipellis perniciosa, were evaluated for their potential to produce hydrolases in liquid medium. Very low or no hydrolytic activity was produced in the absence of any substrate. The activities of chitinase, $\mathrm{N}$-acetylglucosaminidase, $\beta$-1,3-glucanase, total cellulase, endoglucanase, aryl- $\beta$-glucosidase, $\beta$-glucosidase, protease and amylase increased dramatically within $72-120 \mathrm{~h}$ of growth in the presence of specific substrates. Except for $\mathrm{N}$-acetylglucosaminidase and $\beta$-glucosidase Trichoderma harzianum isolate 1051 produced the largest amounts of hydrolases. The possible involvement of these enzymes in the antagonistic interaction between Trichoderma and C. perniciosa is discussed.
\end{abstract}

Key words: Trichoderma, Crinipellis perniciosa, hydrolases, antagonistic interaction

\section{INTRODUCTION}

The basidiomycete fungus Crinipellis perniciosa causes witches' broom disease of cocoa (Theobroma cacao) (2). This fungus is a very destructive pathogen which has a hemibiotrophic life-style, is a species-specific pathogen of cocoa (16) and causes major crop losses in South American and Caribbean plantations (13). Infection is initiated when germ tubes from $C$. perniciosa basidiospores penetrate meristematic tissue within growing apical buds. The host response is localized at the point of infection, where there is considerable tissue enlargement (25) and development of lateral shoots (green brooms) (22). The fungus remains in the primary (biotrophic, monokaryotic) phase for some time within the enlarging green broom, but after 6-9 weeks the green brooms begin to show necrosis. The change is associated with dikaryotization of the fungus to a secondary (saprotrophic, dikaryotic) phase. Subsequently basiciocarps are formed on the dead brooms (22). Breeding for resistance, phytosanitation and the application of fungicides are still the main tools for controlling this disease (5). Nevertheless, fungicides have many undesirable atributes. Novel biocontrol agents have therefore been looked for (7), and Trichoderma isolates have been the preferred choice. Besides other modes of action, cell wall-degrading enzymes such as chitinases $(10,11,19,20)$ and $\beta-1,3$ glucanases $(21,24,28)$, have been associated with the ability of Trichoderma spp to control plant pathogens (26). In fact, a strain of Trichoderma viride offered prospects for biological control of Crinipellis perniciosa (3). Brooms, once colonized, never produced basidiocarps and the contents of cellulose and hemicellulose in brooms infected by the Trichoderma were lower than in uninfected brooms (6). This finding has been correlated with the capacity of Trichoderma to grow faster than C. perniciosa in dual culture (4), and to produce extracellular enzymes on solid media such as cellulase, amylase and proteases (5). Recently, two strains of Trichoderma were found to impair the progress of witches' broom disease in field conditions caused in cocoa by $C$. pernicosa (José L. Bezerra, personal

\footnotetext{
* Corresponding author. Mailing address: Departamento de Biologia Celular, Universidade de Brasília. 70910-900. Brasília - DF, Brasil. E-mail:
} carlosr@unb.br 
communication). We have therefore undertaken a project on evaluation at the potential of these two Trichoderma strains to produce hydrolytic enzymes. Here we report on production of chitinase, $\mathrm{N}$-acetylglucosaminidase, $\beta$-1,3-glucanase, protease, cellulases, and amylase in the presence of the corresponding substrate.

\section{MATERIALS AND METHODS}

\section{Microorganisms and enzyme production}

T. harzianum 39.1 was obtained from the collection of the Microbial Genetics and Biochemistry Group of the University of Nottingham (UK). The other Trichoderma isolates 1051 (Trichoderma harzianum 1051) and TVC (Trichoderma sp) were kindly provided by Dr. Itamar Soares de Melo from the Centro Nacional de Pesquisa de Monitoramento e Avaliação de Impacto Ambiental (CNPMA/EMBRAPA). All microorganisms were maintained on agar medium. For enzyme production, about $3 \mathrm{x}$ $10^{7}$ spores (in one $\mathrm{mL}$ of saline) were transfered to $25 \mathrm{~mL}$ of autoclaved TLE culture medium (19) containing 1\% of either chitin, potato starch, microcristalline cellulose or casein, and $\mathrm{pH}$ adjusted to 5.5. Cultures were then incubated with shaking $(120 \mathrm{rpm})$ at $28^{\circ} \mathrm{C}$. After several time periods, culture supernatants were filtered (Whatman $\mathrm{N}^{\circ} 2$ ) and stored at $-20^{\circ} \mathrm{C}$ until use for determination of enzyme activities.

\section{Enzyme assays}

Chitinase activity (EC 3.2.1.14) was assayed at $37^{\circ} \mathrm{C}$ monitoring the amount of reducing sugar formed from acetylated chitin. $\mathrm{N}$-acetylglucosaminidase activity (EC 3.2.1.30) was measured at $37^{\circ} \mathrm{C}$ using $\rho$-nitrophenyl- $\beta$ - $N$-acetylglucosaminide ( $\rho$-PGlcNAc) as the substrate. $\beta$-1,3-glucanase (EC 3.2.1.39) was assayed based on the release of reducing sugar from laminarin. Reactions were carried out at $37^{\circ} \mathrm{C}$. The reaction systems used were as described previously (19). One unit of enzyme was defined as the amount of enzyme necessary to produce $1 \mu \mathrm{mol}$ of reducing sugar in one minute (chitinase and $\beta$-1,3-glucanase) or $1 \mu \mathrm{mol}$ of $\rho$-nitrophenol in one minute (chitobiosidase).

Total cellulase activity was determined by measuring the amount of reducing sugar formed from filter paper. Reactions were conducted for $60 \mathrm{~min}$ at $50^{\circ} \mathrm{C}(29)$. One unit of total cellulase activity correspond to the amount of reducing sugar produced in one minute.

Endoglucanase activity (EC 3.2.1.4) was assayed by measuring the amount of reducing sugar formed from carboxymethylcellulose (CM-cellulose). The reaction system contained 0-250 $\mu \mathrm{L}$ of enzyme solution and $500 \mu \mathrm{L}$ of sodium citrate buffer $(50$ $\mathrm{mol} / \mathrm{L}$ ), pH 6.0, containing 1\% CM-cellulose (low viscosity). Reactions were allowed to proceed for $60 \mathrm{~min}$ at $50^{\circ} \mathrm{C}$ and stopped with $1.5 \mathrm{~mL}$ of dinitrosalicilate reagent. One unit of endoglucanase activity was defined as the amount of protein necessary to produce one mmol of reducing sugar in one minute. $\beta$-glucosidase activity (cellobiosidase, EC 3.2.1.21) was assayed by measuring production of glucose from cellobiose. Reactions were conducted for $30 \mathrm{~min}$ at $50^{\circ} \mathrm{C}$. Aryl- $\beta$-glucosidase (EC 3.2.1.2) was assayed by monitoring the amount of $\rho$ nitrophenol formed in $10 \mathrm{~min}$ at $42^{\circ} \mathrm{C}$ from $\rho$-nitrophenol- $\beta$-D glucopyranoside. The reaction systems were as previously described (29). One unit of cellobiosidase or aryl- $\beta$-glucosidase activity was defined as to the amount of protein necessary to produce $1 \mathrm{mmol}$ of glucose or $\rho$-nitrophenol respectively, in one minute.

Protease (EC 3.4.) was assayed using "Hammarsten" casein as described by Santos et al. (27). One unit of protease activity was defined as the amount of enzyme necessary to cause a change of one unit in the absorbance of the supernatant in 20 $\min$.

Amylase dextrinizing activity was assayed by measuring the change of blue values of amylose-iodine complexes. The reaction was allowed to proceed for $30 \mathrm{~min}$ at $40^{\circ} \mathrm{C}(9)$. One unit of dextrinizing activity was defined as the amount of enzyme which hydrolyses $0.1 \mathrm{mg}$ of soluble starch in one minute.

\section{RESULTS AND DISCUSSION}

Trichoderma harzianum isolate 1051 and Trichoderma sp. isolate TVC were previously shown to effectively control witches'broom disease of cocoa caused by C. perniciosa in field conditions (José L. Bezerra, personal communication). This is in agreement with the report that $T$. viride decreased the incidence of fruits infected by C. perniciosa $(5,6)$. Trichoderma spp are able to parasitise a wide range of fungal hosts of varied cell wall structure and composition. Microscopic examination revealed formation of hyphal coiling and formation of short lateral branches by $T$. viride when associated with $C$. perniciosa (5). Additional studies revealed that lytic enzymes such as proteases, amylases, and cellulases, but not antibiotics, were produced by the antagonist. Therefore, the killing of the $C$. perniciosa in culture, and in dry brooms of cocoa, coupled with the absence of an active antibiotic support the idea that the most important mechanism involved in this host-parasite interaction seems to be mycoparasitism.

Both Trichoderma isolates tested produced and secreted on induction substantial amounts of chitinolytic and glucanolytic enzymes, in comparision to T. harzianum strain 39.1 under the same growth conditions. The chitinase increased within $72 \mathrm{~h}$. Maximal activity $(0.39 \mathrm{U} / \mathrm{mL})$ was produced by isolate 1051 . This activity was 45 -fold and 13-fold higher than those determined for the TVC $(0.085 \mathrm{U} / \mathrm{mL})$ and $39.1(0.013 \mathrm{U} / \mathrm{mL})$ strains, respectively (Fig. 1A). The highest $\mathrm{N}$-acetyl-glucosaminidase activities were produced by isolate $1051(0.41 \mathrm{U} / \mathrm{mL})$ and strain $39.1(0.47 \mathrm{U} / \mathrm{mL})$ grown for $72 \mathrm{~h}$. The activity produced by strain TVC $(0.01 \mathrm{U} / \mathrm{mL})$ at $72 \mathrm{~h}$ was 47 -fold smaller (Fig. 1B). The chitinolytic activity induced by chitin in $T$. harzianum comprises 

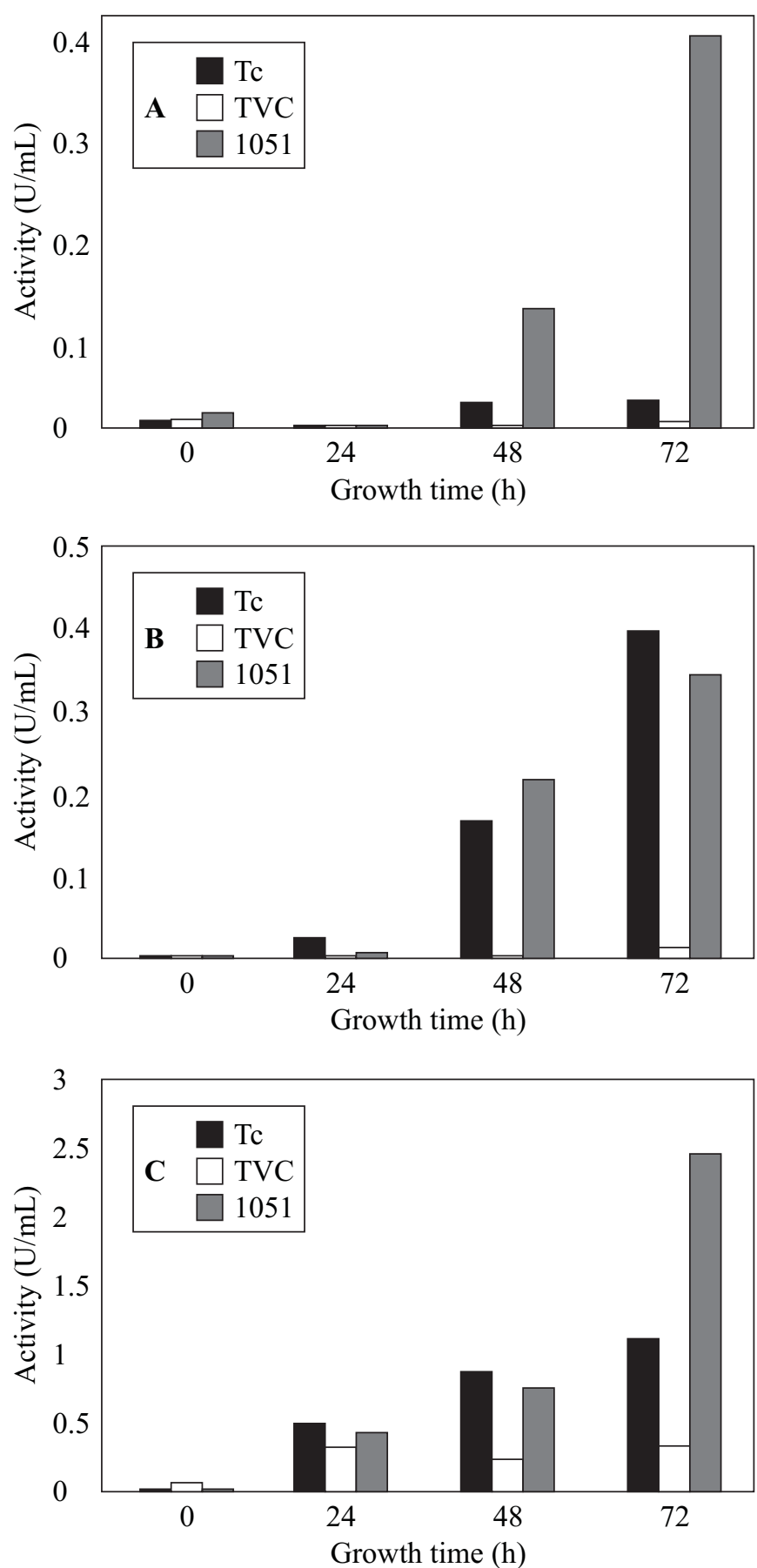

Figure 1. Chitinase (A), N-acetylglucosaminidase (B) and 1,3glucanase (C) activities in the culture medium of Trichoderma harzianum isolate 1051, Trichoderma sp. isolate TVC and Trichoderma harzianum 39.1 (Tc).

at least four endochititinases, two $\mathrm{N}$-acetyl-glucosaminidase and one exochitinase (17). The highest $\beta$-glucanase activity (2.8 U/ $\mathrm{mL}$ ) was also produced by T. harzianum isolate 1051 after $72 \mathrm{~h}$ of growth. This activity was 7.2-fold and 2.2-fold higher than the activity produced by $T$. harzianum $\mathrm{Tc}(1.27 \mathrm{U} / \mathrm{mL})$ and isolate TVC $(0.38 \mathrm{U} / \mathrm{mL})$, respectively (Fig. $1 \mathrm{C})$. The enzyme activities found in non-induced cultures (not shown) were very low or absent. Chitinolytic enzymes and $\beta$-glucanases are thought to play an important role in the mycoparasitism between Trichoderma spp and phytopathogens. We have recently demonstrated that a 46-kDa chitinase (CHIT 46) drastically affects in vitro, the cell walls of the phytopathogens Sclerotium rolfsii and Rhizoctonia solani (19). This CHIT 46 chitinase was shown to be secreted into the culture medium as soon as $2 \mathrm{~h}$ after the fungus comes into contact with chitin (20). Fungal cell walls are complex structures consituted almost exclusively of polysaccharides such as $\beta$-glucan (cellulose, $\beta$-1,3-and $\beta$-1, 6 glucan) and chitin (12). These polysaccharides may well act as inducers of hydrolytic enzymes during the antagonistic interaction of Trichoderma with C. perniciosa. In fact, the purified chitinase produced by Trichoderma harzianum isolate 1051 considered in this work was shown to effect " in vitro" the $C$. perniciosa cell wall (10).

Trichoderma spp. are known to produce cellulases (23) which hydrolyse $\beta$-1,4-glucans. In accordance, all three Trichoderma isolates were found to produce substantial amounts of these enzymes. The highest total cellulase (Fig. 2A) and endoglucanase (Fig. 2B) activities were produced by isolate 1051 after $120 \mathrm{~h}$ of growth. However, although the cellobiase activity $(0.503 \mathrm{U} / \mathrm{mL})$ produced by isolate 1051 after $120 \mathrm{~h}$ of growth was 2.64 -fold higher than that produced by isolate TVC $(0.19 \mathrm{U} / \mathrm{mL})$ after the same time of growth, this activity was 1.22 -fold lower than that $(0.616 \mathrm{U} / \mathrm{mL})$ produced by strain 39.1 (Fig. 3A). The aryl- $\beta$-glucosidase activity produced by both isolates 1051 and TVC were smaller than that of produced by 39.1 (Fig.3B). Basidiomycetes belong to a group of fungi which have chitin and glucans (probably $\beta-1,3$ and $\beta$-1,6-glucans) as main components of their cell walls (8). The $\beta$-1,4-glucanolytic enzymes produced by Trichoderma may well be involved in hydrolysis of the $C$. perniciosa cell wall glucans during antagonism. Alternatively, hydrolysis of the cellulose present elsewhere by cellulases would attend the Trichoderma parasite metabolic needs.

Filamentous fungal cell walls also contains lipids and proteins (18). It therefore expected that antagonistic fungi synthesize proteases which may act on the host cell-wall. The Trichoderma isolates 1051 and TVC secreted equivalent amounts (about $1.41 \mathrm{U} / \mathrm{mL}$ ) of proteolytic activity after $72 \mathrm{~h}$ of growth. These activities were significantly higher than that $(0.86$ $\mathrm{U} / \mathrm{mL}$ ) produced by T. harzianum strain 39.1 under the same conditions (Fig. 4). An alkaline protease (Prb1) from $T$. harzianum strain IMI which was induced by chitin, autoclaved mycelia and fungal cell-walls was suggested to be involved in mycoparasitism (15). This assumption was further supported by the fact that direct confrontation assays between $T$. 

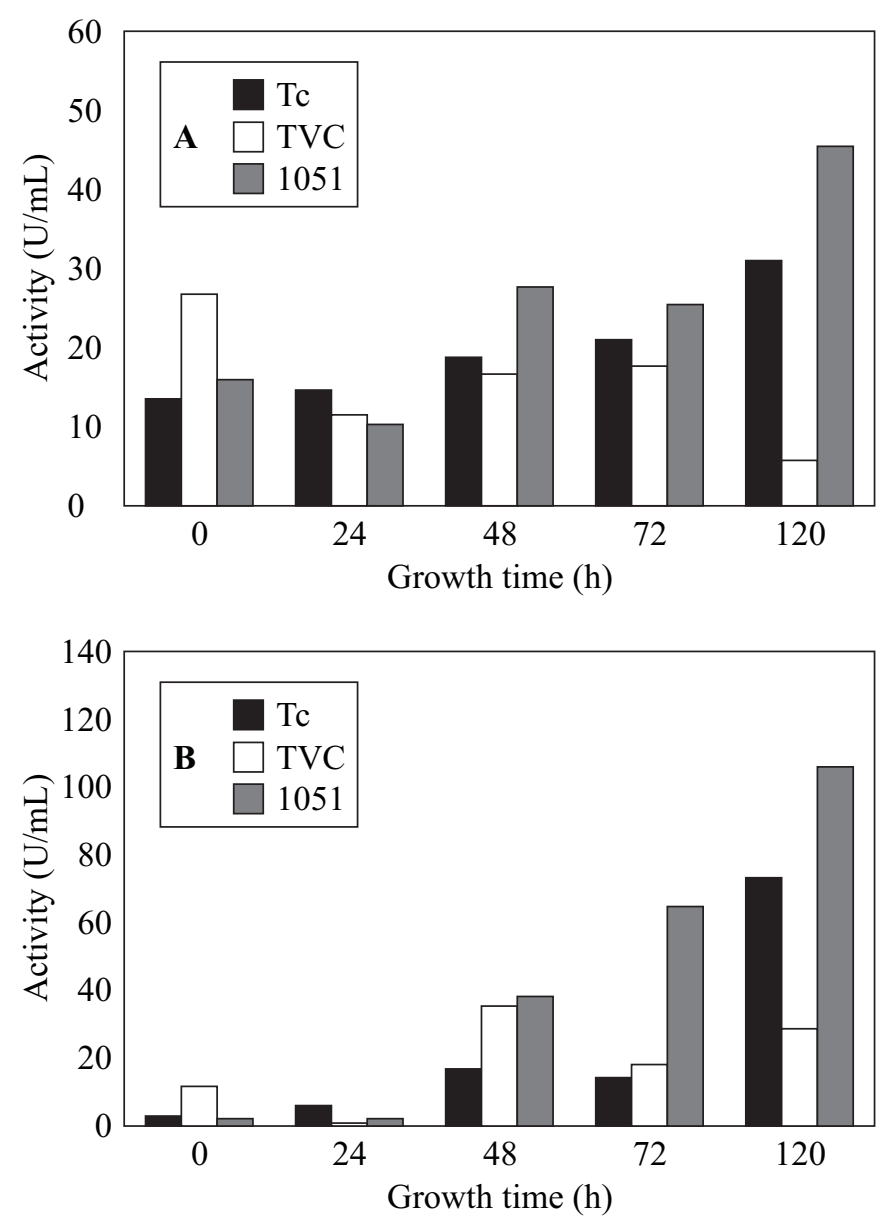

Figure 2. Total cellulase (A) and endoglucanase (B) activities in the culture medium of Trichoderma harzianum isolate 1051, Trichoderma sp. isolate TVC and Trichoderma harzianum 39.1 (Tc).

harzianum strain IMI 206040 and Rhyzoctonia solani resulted in induction of Pbr1 mRNA synthesis (14). The protease produced by the T. harzianum isolate 1051 was purified and tested for its ability to hydrolysis the C. perniciosa cell wall. It does affect the phytopathogen "in vitro" (11).

The Trichoderma isolate 1051 and strain 39.1, also produced amylolytic dextrinizing activity $(2.66 \mathrm{U} / \mathrm{mL})$ which were about 221 -fold higher than that produced by isolate TVC within $60 \mathrm{~h}$ of growth (Fig. 5). In all cases, the activity produced in the absence of starch was insignificant, thereby indicating an inductive process. There is no report of the presence of starch in fungal cell walls. However, glycogen which is a closely related polysaccharide is present in the cell walls of some fungi (8). The Basidiomycetes group, which includes C. perniciosa, doesn't belongs to this particular class of fungi. In this case, the amylases could act non-specifically on the C. perniciosa cell wall. However, electron microscopy studies using the $T$.
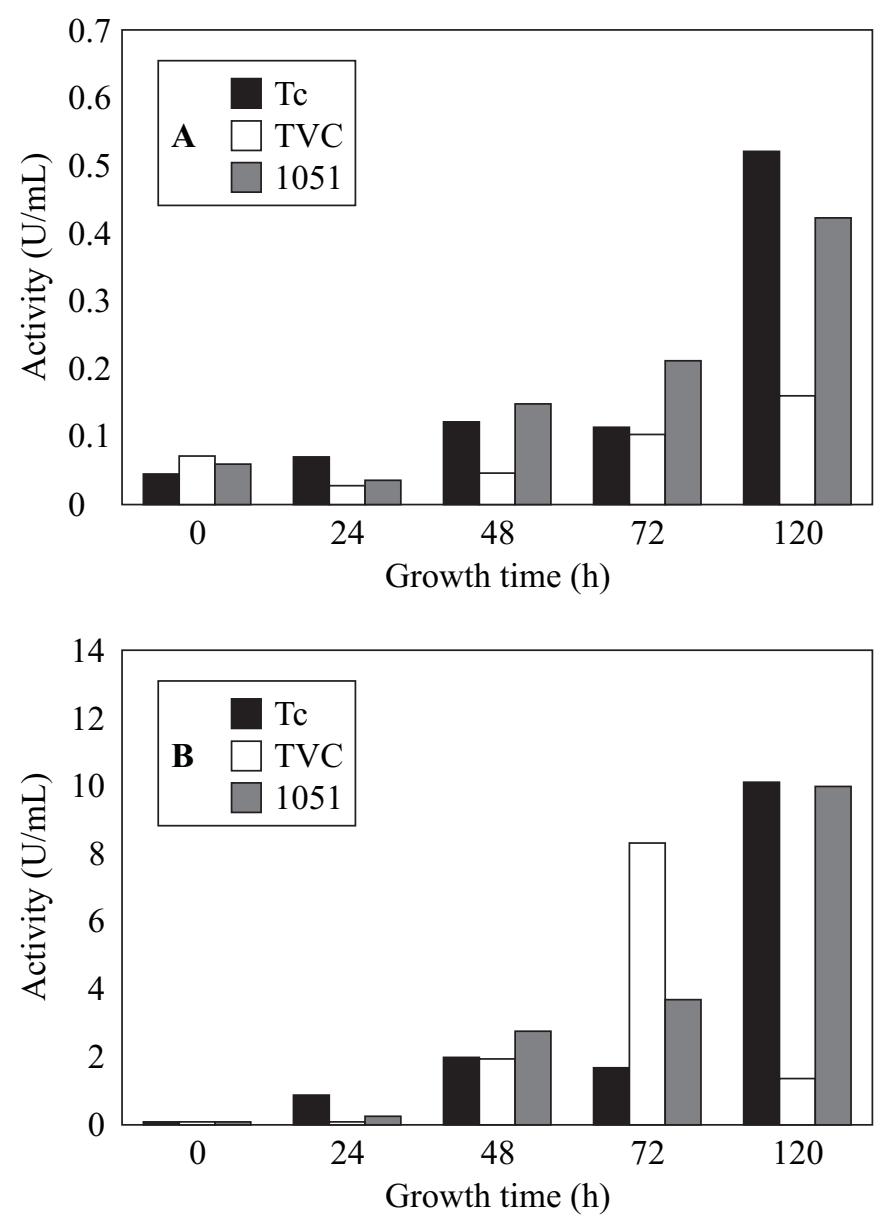

Figure 3. Glucosidase (A) and aryl-D-glucosidase (B) activities in the culture medium of Trichoderma harzianum isolate 1051, Trichoderma sp. isolate TVC and Trichoderma harzianum 39.1 (Tc).

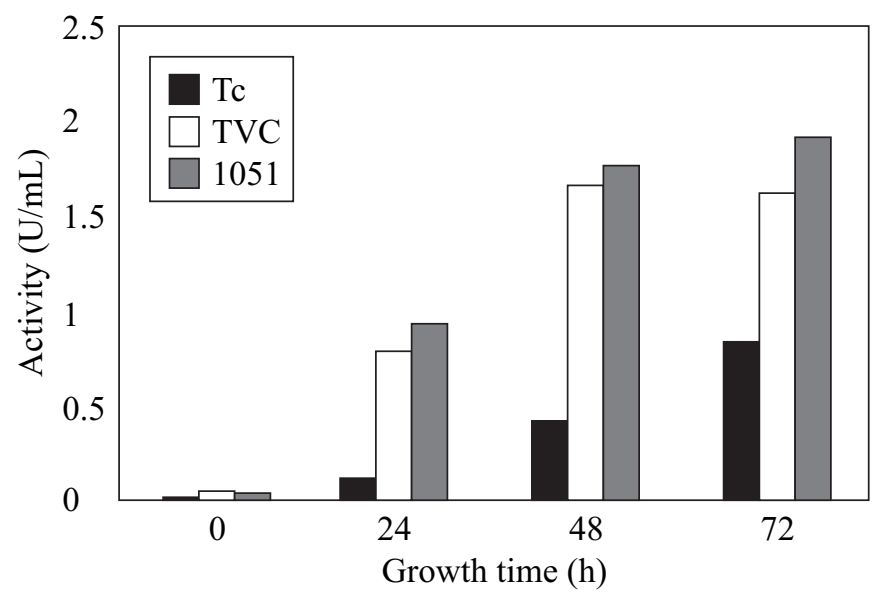

Figure 4. Protease activity in the culture medium of Trichoderma harzianum isolate 1051, Trichoderma sp. isolate TVC and Trichoderma harzianum 39.1 (Tc). 


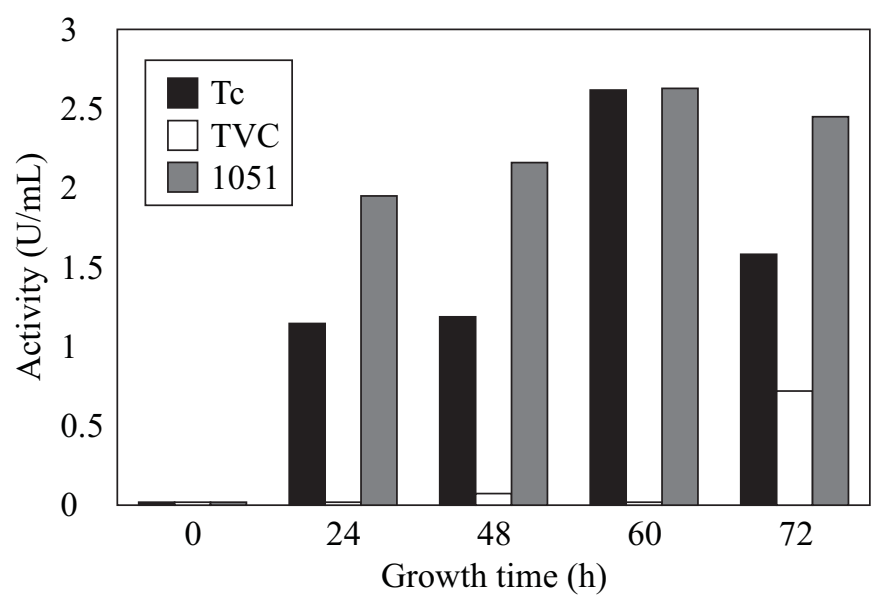

Figure 5. Amylase dextrinizing activity in the culture medium of Trichoderma harzianum isolate 1051, Trichoderma sp. isolate TVC and Trichoderma harzianum 39.1 (Tc).

harzianum isolate 1051 purified amylase showed that this enzyme has no action on the phytopathogen cell wall (1). Alternatively, as starch is widely distributed in nature, these enzymes could assist saprophytic survival by degrading starch present elsewhere.

\section{RESUMO}

\section{Produção de enzimas hidroliticas por cepas de Trichoderma, com atividade antagonista contra Crinipellis perniciosa, agente causador da "vassoura-de-bruxa" no cacau}

Dois isolados de Trichoderma os quais reduzem a incidência da doença "vassoura-de-bruxa", causada em plantações de cacau pelo fungo Crinipellis perniciosa, foram avaliados quanto ao seu potencial de produção de hidrolases em meio líquido. $\mathrm{Na}$ ausência de qualquer substrato nenhuma atividade hidrolítica foi produzida. As atividades de quitinase, $\mathrm{N}$-acetilglicosaminidase, $\beta$-1,3-glucanase, celulase total, endoglucanase, aril- $\beta$-glucosidase, $\beta$-glucosidase, protease e amilase aumentaram significativamente durante o crescimento dos isolados em meio líquido contendo os respectivos substratos. As maiores atividades foram encontradas nos tempos de 72 a 120 horas de crescimento. Com exceção das enzimas $\mathrm{N}$-acetilglicosaminidase e $\beta$-glucosidase, os maiores níveis de hidrolases foram encontrados nas culturas do isolado 1051 de Trichoderma harzianum. O possível envolvimento destas enzimas na interação antagonística entre Trichoderma e $C$. perniciosa é discutido.

Palavras-chave: Trichoderma, Crinipellis perniciosa, hidrolases, interação antagonística.

\section{ACKNOWLEDGMENTS}

J.L.M. acknowledges the post doctoral scholarship from Conselho Nacional de Desenvolvimento Científico e Tecnológico- $\mathrm{CNPq}$.

\section{REFERENCES}

1. Azevedo, A.M.C.; De Marco, J.L.; Felix, C.R. Production of hydrolytic enzymes by Trichoderma sp. isolate with antagonistic activity against Crinipellis perniciosa, the causal agent of witches'broom of cocoa. Fems Microbiol. Lett., 188: 171-175, 2000.

2. Baker R.E.D.; Holliday P. Witches'broom disease of cocoa (Marasmius perniciosus Stahel). Phytopathology Paper $\mathrm{N}^{\circ}$. 2, Kew, UK: Commonwealth Mycological Institut, 1957

3. Bastos C.N. Estudos desenvolvidos e perspectivas de controle biológico de vassoura-de-bruxa do cacaueiro. Comunicado Técnico, CEPLAC, Belém, PA, no. 24. 1991. 4p.

4. Bastos C.N. Potencial de Trichoderma viride no controle da vassourade-bruxa (Crinipellis perniciosa) do cacaueiro. Fitopatol. bras., 21: 509-512, 1996a.

5. Bastos C.N. Mycoparasitic nature of the antagonism between Trichoderma viride and Crinipellis perniciosa. Fitopatol. bras., 21: 50-54, 1996b.

6. Bastos C.N.; Dias C.J. Redução na produção de Basidiocarpos de Crinipellis perniciosa por Trichoderma viride. Summa Phytopatol., 18: 235-238, 1992.

7. Boland G.J. Biological control of plant diseases with fungal antagonists: challenges and opportunities. Can. J. Plant Pathol., 12: 295-299, 1990.

8. Bartinicki-Garcia S. Cell wall chemistry, morphogenesis, and taxonomy of fungi. Ann. Ver. Microbiol., 22: 87-109, 1968.

9. Campos L., Felix C.R. Purification and characterization of a glucoamylase from Humicola grisea. Appl. Environm. Microbiol., 61: 2436-2438, 1995.

10. De Marco, J.L.; Lima, L.H.; Sousa, M.V.; Felix, C.R. A Trichoderma harzianum chitinase destroys the cell wall of the phytopathogen Crinipellis perniciosa, the causal agent of witches'broom disease of cocoa. World J. Microbiol. Biotechnol., 16: 383-386, 2000.

11. De Marco, J.L.; Felix, C.R. Characterization of a protease produced by a Trichoderma harzianum isolate which controls cocoa plant witches'broom disease. BMC Biochemistry, http:// www.biomedcentral.com/1472-2091/3/3, 2002

12. Debono M.; Gordee R.S. Antibiotics that inhibit fungal cell wall development. Ann. Rev. Microbiol., 48: 471-497, 1994.

13. Evans H.C. Pleomorphism in Crinipellis perniciosa, causal agent of witches'broom disease of cocoa. Trans. Br. Mycol. Soc., 74: 515-23, 1980.

14. Flores A.; Chet, I.; Herrera-Estrella A. Improved biocontrol activity of Trichoderma harzianum strains by over-expression of the proteinase encoding gene prb1. Curr. Gen., 31: 30-37, 1997.

15. Geremias R.; Goldman, G.H.; Jacobs, D.; Ardiles, W.; Vila, S.B.; van Montagu, M.; Herrera-Estrela, A. Molecular characterization of the proteinase-encoding gene prb1, related to mycoparasitism by Trichoderma harzianum. Mol. Microbiol., 8: 603-613, 1993.

16. Griffiths, G.W.; Hedger, J.N. The breeding biology of biotypes of the witches'broom pathogen of cocoa Crinipellis perniciosa. Heredity, 2: 278-289, 1994.

17. Haran, S.; Schickler, H.; Chet, I. Molecular mechanisms of lytic enzymes involved in the biocontrol activity of Trichoderma harzianum. Microbiology, 142: 2321-2331, 1996.

18. Hunsley, H.D.; Burnett, J.H. The ultrastructural architecture of the walls of some hyphal fungi. J. Gen. Microbiol., 62: 203-218, 1970.

19. Lima, L.H.C.; Ulhoa, C.J.; Fernandes, A.P.; Felix, C.R. Purification of a chitinase from Trichoderma sp and its action on Sclerotium rolfsii and Rhizoctonia solani cell walls. J. Gen. Appl. Microbiol., 43: 31-37, 1997 . 
20. Lima, L.H.C.; De Marco, J.L.; Ulhoa, C.J.; Felix, C.R. Synthesis of Trichoderma chitinase which affects the Sclerotium rolfsii and Rhizoctonia solani cell walls. Folia Microbiol., 44(1): 45-49, 1999.

21. Lorito, M.; Hayes, C.K.; Di Pietro, A.; Woo, S.L.; Harman, G.E. Purification, characterization, and synergistic activity of a glucan $\beta$ 1,3-glucosidase and an N-acetyl- $\beta$-glucosaminidase from Trichoderma harzianum. Phytopathology, 84: 398-405, 1994.

22. Muse, R.B.; Collin, H.A.; Isaac, S.; Hardwick, K. Effects of the fungus Crinipellis perniciosa, causal agent of witches'broom disease, on cell and tissue cultues of cocoa (Theobroma cacao L.). Plant Pathol., 45: 145-154, 1996.

23. Nevalainen, H.; Penttilä, M. Molecular biology of cellulolytic fungi. In: The Mycota II. Genetics and Biotechnolog. Edt. U. Kuck. SpringerVerlag, Berlin, 1995, p. 303-319.

24. Noronha, E.F.; Ulhoa, C.J. Purification and characterization of an endo- $\beta$-1,3-glucanase from Trichoderma harzianum. Can. J. Microbiol., 42: 1039-1044, 1996.
25. Orchcard, J.; Collin, H.A.; Hardwick, K.; Isaac, S. Changes in morphology and measurement of cytokinin levels during the development of witches' brooms of cocoa. Plant Pathol., 43: 6572, 1994

26. Papavizas, G.C. Trichoderma and Gliocladium: biology, ecology and potential for biocontrol. Ann. Rev. Phytopat., 23: 23-54, 1985.

27. Santos, R.D.B.; Firmino, A.; de Sá, C.M.; Felix, C.R. Keratinolytic activity of Aspergillus fumigatus Fresenius. Curr. Microbiol., 33: 364-370, 1996.

28. Schirmbock, M.; Lorito, M.; Wang, U.L.; Hayes, C.K.; Arisan-Atac, I.; Scala, F.; Harman, G.; Kubicek, C. Parallel formation and synergism of hydrolytic enzymes and peptaibol antibiotics, molecular mechanisms involved in the antagonistic action of Trichoderma harzianum against phytopathogenic fungi. Appl. Environ. Microbiol., 60: 4364-4370, 1994.

29. Ximenes, E.A.; Felix, C.R.; Ulhoa, C.J. Production of Cellulases by Aspergillus fumigatus and characterization of one $\beta$-glucosidase. Curr. Microbiol., 33: 119-123, 1996. 